\title{
Storms, Streams, and Reservoirs- Assessing Water Quality in the Cambridge, Massachusetts, Drinking-Water Source Area
}

From September 1997 through November 1998, the U.S. Geological Survey (USGS), in cooperation with the City of Cambridge, Massachusetts, Water Department (CWD), studied the water quality of Cambridge's three drinking-water supply reservoirs and their tributary streams. Although highway and urban stormwater runoff adversely affected some tributaries, the reservoir system ultimately delivered high-quality water to the treatment plant. Using data from this study, the USGS and CWD developed a comprehensive monitoring program for the drinking-water source area and designed a new investigation that examines how storm-water runoff affects tributary- and reservoir-water quality.

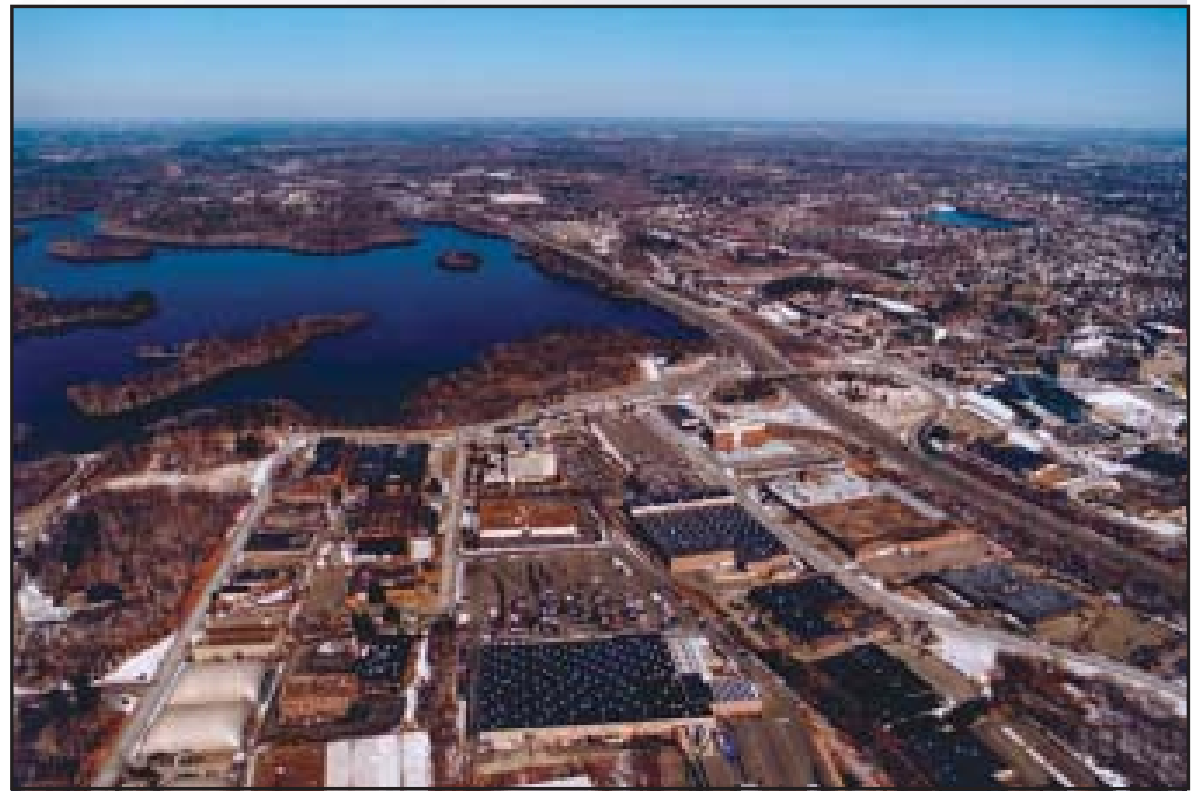

Figure 2. Aerial photo of Hobbs Brook Reservoir in the Cambridge, Massachusetts, drinkingwater source area. Photo by Joseph R. Melanson, Aero Photo, Inc.,Wareham, Massachusetts.

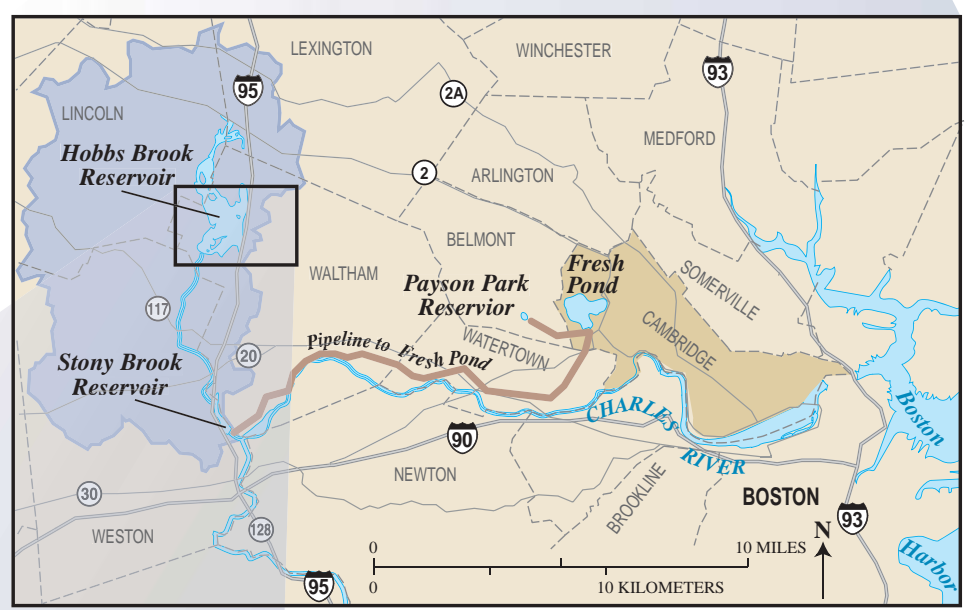

Figure 1. Location and extent of the Cambridge, Massachusetts, drinkingwater-supply system.

\section{The USGS and CWD Partnership}

Every day, the CWD supplies roughly 15 million gallons of water to more than 100,000 customers. A system of reservoirs in Cambridge and in parts of five other suburban Boston communities supplies most of this water (fig. 1). The heavily developed drainage basin that contributes water to these reservoirs contains major highways, secondary roads, and areas of residential, commercial, and industrial land use that could adversely affect the water supply. The City of Cambridge, however, owns less than 5 percent of the land in the basin. Consequently, the CWD relies heavily on water-quality monitoring to determine if contaminants enter the water supply from land it does not own.

As part of its mission to understand and help protect the quality of our Nation's water resources, the U.S. Geological Survey conducts investigations that help municipal water suppliers manage their local drinking-water resources. One such study, begun in 1997 in cooperation with the City of Cambridge and completed in 1998, was designed to identify sources of contaminants in the city's drinking-water 
source area. Data from this study were then used to select sampling stations for a water-quality monitoring network in the source area.

In beginning the study, the USGS and CWD outlined three objectives. We planned to characterize current water-quality conditions in the drinking-water source area, to identify tributaries most likely to transport contaminants to the reservoirs, and to provide baseline information about contaminant loads, which will help evaluate the effectiveness of watershed

best-management practices. Waldron and Bent (2001) provide details of the water-quality study and completely describe the water-quality monitoring program.

This Fact Sheet summarizes the major findings of the study and briefly describes the water-quality monitoring program developed from them. It also provides an overview of the current (2002) USGS cooperative investigation with the CWD that is examining the effects of stormwater runoff on the water supply.

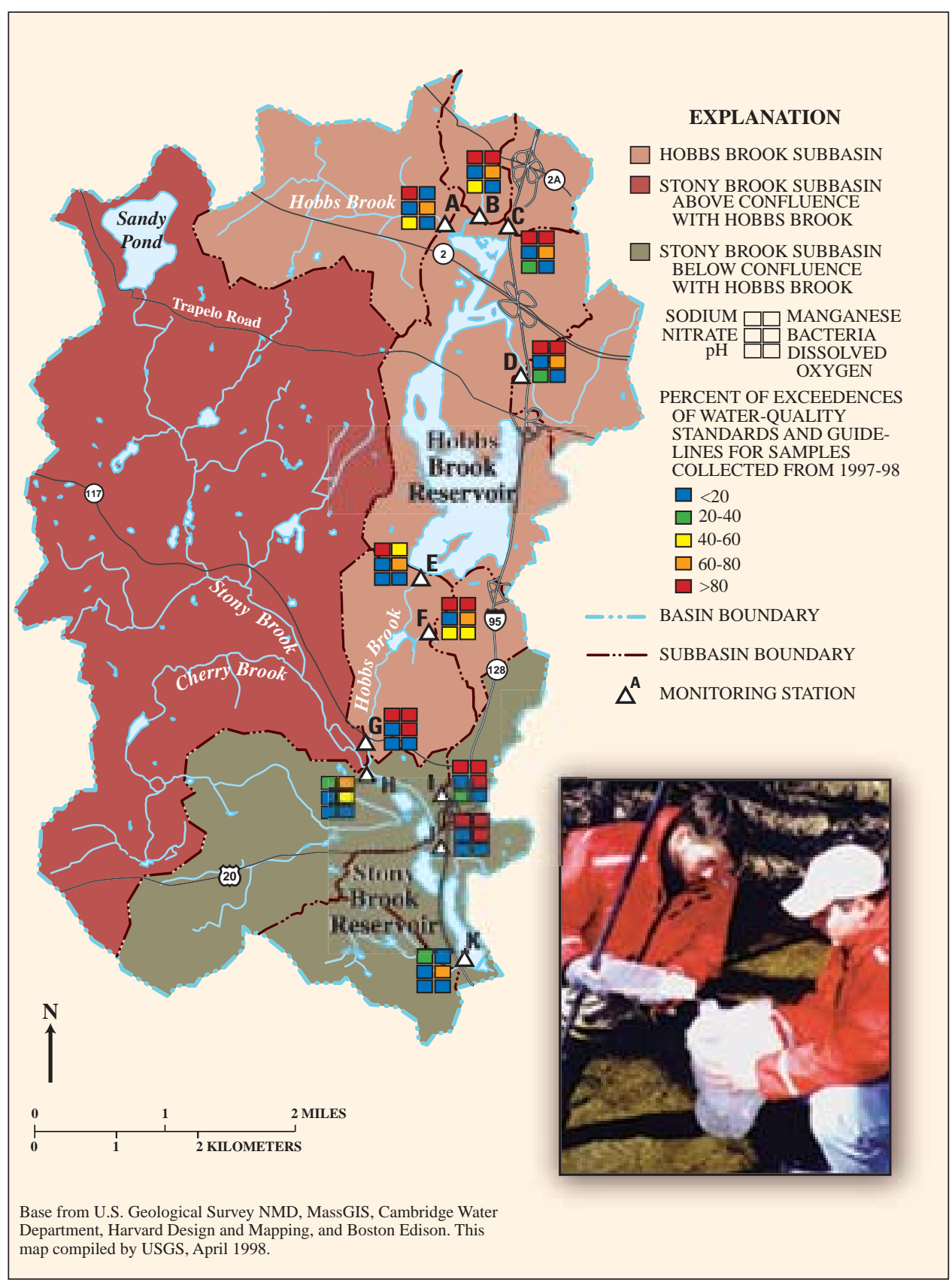

Figure 3. Concentrations of selected contaminants in the study area in relation to applicable State and Federal water-quality standards. Photo inset shows U.S. Geological Survey and Cambridge Water Department staff collecting stream samples.

\section{Cambridge's Drinking- Water Supply System}

The Cambridge drinking-water supply system consists of Hobbs Brook and Stony Brook Reservoirs, which drain 15,200 acres in Lexington, Waltham, and Weston, and Fresh Pond, a 155-acre kettle-hole lake in Cambridge (fig. 1). Several tributaries and storm drains associated with State Routes 128 and 2 , secondary roads, and commercial and industrial parking areas feed Hobbs Brook Reservoir (fig. 2). Drainage from the Stony Brook Subbasin, outflow from Hobbs Brook Reservoir, and other small tributaries flow into Stony Brook Reservoir. The CWD pipes water from Stony Brook Reservoir to Fresh Pond, where it remains before treatment. After treatment, the CWD pumps the finished water to Payson Park Reservoir in Belmont. From there, it flows by gravity through a 190-mile distribution system.

\section{Study Design}

To achieve the study objectives, a dual sampling strategy was developed. First, 11 streams that carry water to Hobbs Brook and Stony Brook Reservoirs were sampled for streamflow and water-quality conditions. These data demonstrated how land use, land cover, and other drainage-basin characteristics affected the sources, transport, and fate of potential drinking-water contaminants. The second part of the study was an ecological assessment of the three primary storage reservoirs-Hobbs Brook Reservoir, Stony Brook Reservoir, and Fresh Pond. These assessments provided baseline information and helped determine the reservoirs' vulnerability to increased loads of nutrients and other contaminants.

\section{Tributary Water Quality}

Concentrations of potential drinking-water contaminants varied throughout the Hobbs Brook and Stony Brook Subbasins, and the subbasins differed in their relative contributions to total contaminant loads. Waldron and Bent (2001) provide details on streamflow estimates for the 11 streams sampled and discuss methods for sampling and calculating annual contaminant loads. 
Concentrations of FecalColiform Bacteria Higher in Streams in the Hobbs Brook Subbasin than in Streams in the Stony Brook Subbasin

Water samples from streams in the heavily developed Hobbs Brook Subbasin generally had higher concentrations of fecal-coliform bacteria than those found in samples from the more residential Stony Brook Subbasin. When total annual contributions of bacteria were compared, however, the two subbasins, which are about equal in area, contributed about the same amount of bacteria to the water supply.

At all monitoring stations, fecalcoliform concentrations frequently exceeded the State drinking-water source-area standard of 20 CFU/100 $\mathrm{mL}$ (colony-forming units per 100 milliliters). Specifically, between 60 and 80 percent of samples from streams that flow to Hobbs Brook Reservoir (stations A, B, C, and D) exceeded the State standard (fig. 3). More than 80 percent of samples collected at the mouth of Hobbs Brook (station G), at Stony Brook downstream from the Hobbs Brook confluence (station J), and at one small tributary to Stony Brook (station I) exceeded the standard. In contrast, 40 to 60 percent of samples collected from Stony Brook upstream from the mouth of Hobbs Brook (station $\mathrm{H}$ ) had bacteria concentrations above the standard.

Higher bacteria concentrations from the Hobbs Brook Subbasin most likely result from the subbasin's large surface area that is impervious to water. This subbasin contains more roads, buildings, and parking lots, and more densely populated residential areas, than the Stony Brook Subbasin. Precipitation falling on these surfaces is more likely to carry bacteria from bird and animal waste, as well as other contaminants, directly to the streams.

The total mass of a contaminant that is transported downstream past a monitoring station in one year is defined as the annual contaminant load for the stream. By expressing the loads on a per-square-mile basis, contaminant loads for streams that drain large subbasins can be compared with those for streams draining smaller subbasins. This value, which is an indication of the relative magnitude of a contamination problem, is referred to as the subbasin yield.

The subbasin yield of fecalcoliform bacteria at station $\mathrm{E}$, which represents the outflow from Hobbs Brook Reservoir, was small relative to the yields of the inflowing tributaries (A, B, C, and D, fig. 4A), indicating that the reservoir attenuated the effects of the relatively high bacteria loads from the tributaries, probably through dilution, settling, and death. Interestingly, the subbasin yield at station $\mathrm{G}$ was much larger than that at station $\mathrm{E}$ or station $\mathrm{F}$, which are directly upstream from station $\mathrm{G}$. This indicates that there may have been additional sources of fecalcoliform bacteria in the lower Hobbs Brook Subbasin downstream from the reservoir. Subbasin yields were greatest at station I, which drains a section of State Route 128 and a steeply sloped industrial area. Yields were smallest at station $\mathrm{K}$, which drains primarily low-density residential areas with only locally maintained roads.

\section{Most Streams Meet Dissolved Oxygen Standard}

Except for a small tributary (station F) that drains a heavily developed area south of Hobbs Brook Reservoir, streams in the study area rarely had dissolved oxygen concentrations lower than the State standard of $6 \mathrm{mg} / \mathrm{L}$ (milligrams per liter) (fig. 3). Dissolved oxygen concentrations lower than the standard can indicate the presence of organic wastes or excess plant nutrients, such as nitrogen and phosphorus, which would impair water quality.

\section{pHValues below State Standard in Several Streams}

Although most streams had adequate dissolved oxygen concentrations, several streams had $\mathrm{pH}$ values below the State standard of 6.5. Forty to sixty percent of $\mathrm{pH}$ values from stations A, B, and F, and 20-40 percent of those from stations C, D, and I were below the State standard (fig. 3). Most of these low $\mathrm{pH}$ values reflect the presence of naturally occurring organic acids leached from wetlands in the tributary drainage basins.
Unlike for $\mathrm{pH}$, no State or Federal standards govern concentrations of sodium, nitrate, or manganese in surface waters. The U.S. Environmental Protection Agency (USEPA), however, has established a drinking-water equivalent (DWEL) guideline of 20 $\mathrm{mg} / \mathrm{L}$ for sodium, a drinking-water maximum contaminant level (MCL) of $10 \mathrm{mg} / \mathrm{L}$ for nitrate, and secondary maximum contaminant levels (SMCL) of $250 \mathrm{mg} / \mathrm{L}$ for chloride and $50 \mu \mathrm{g} / \mathrm{L}$ (micrograms per liter) for manganese (U.S. Environmental Protection Agency, 1998; 2001). Because these constituents often are difficult and expensive to remove during drinking-water treatment, it helps to compare the finished water guidelines with measured concentrations from stream samples.

\section{Sodium and Chloride Concentrations Linked to Application of Road-Deicing Salt}

Dissolved sodium concentrations from the Hobbs Brook Subbasin frequently exceeded the USEPA's DWEL. When annual subbasin yields of dissolved sodium were compared, the Hobbs Brook Subbasin (station G) contributed more than three times the amount of dissolved sodium than that contributed by the Stony Brook Subbasin (station H) (fig. 4B).

At all but two monitoring stations, $\mathrm{H}$ and $\mathrm{K}$, which drain low-density residential parts of the Stony Brook Subbasin, 80 percent of sodium concentrations exceeded the USEPA guideline (fig. 3). The stations with the highest concentrations $(\mathrm{B}, \mathrm{C}$, and D) were heavily affected by runoff from State Routes 2 and 128. In fact, annual subbasin yields of sodium and chloride were statistically highly correlated with the percentage of subbasin area occupied by roads (Waldron and Bent, 2001).

This correlation indicates that the application of sodium chloride in road salt was a significant source of these ions. The greater contribution from the Hobbs Brook Subbasin also reflects the relatively high density of State-maintained highways in that subbasin (4.3 percent of total area) in comparison to that of the Stony Brook Subbasin (0.4 percent of total area.) 


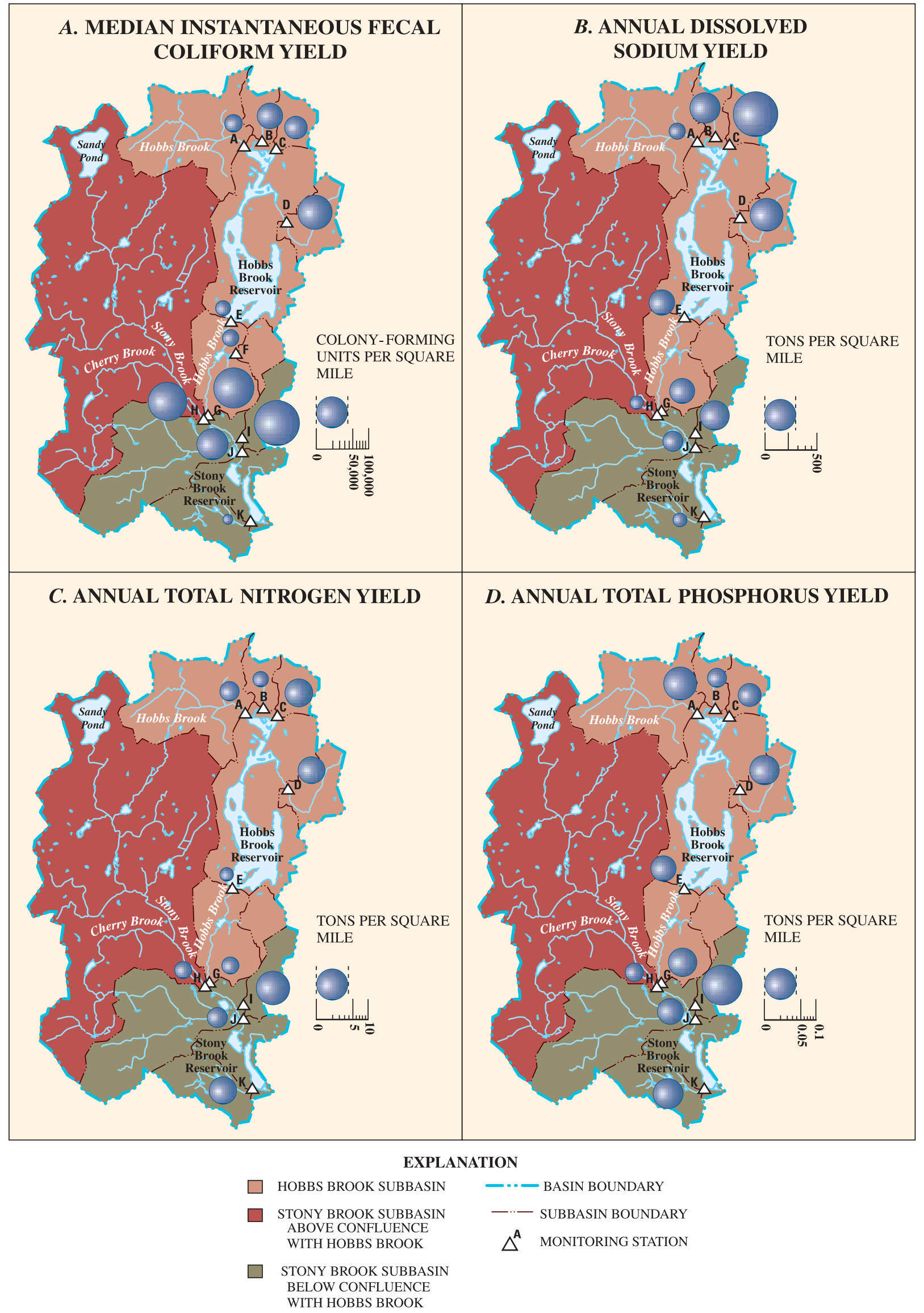

Figure 4. Median instantaneous subbasin yields of fecal-coliform bacteria $(A)$ and annual subbasin yields of $(B)$ dissolved sodium, $(C)$ total nitrogen, and $(D)$ total phosphorus for streams in the Cambridge, Massachusetts, drinking-water source area. 
Nitrate Levels Low throughout System, but Phosphorus High in Hobbs Brook Subbasin

Nitrate concentrations did not exceed the USEPA's MCL at any station during the study period. Typically, concentrations were less than one tenth of the MCL.

Total annual subbasin yields of total nitrogen from the Hobbs Brook Subbasin (station G) and the Stony Brook Subbasin above the Hobbs Brook confluence (station $\mathrm{H}$ ) differed little (fig. 4C). In contrast, the annual subbasin yield of total phosphorus for the Hobbs Brook Subbasin was nearly three times that of the Stony Brook Subbasin (fig. 4D). Subbasin yields of both constituents from a small, largely residential subbasin (station K) that discharges directly into Stony Brook Reservoir were unexpectedly high, as were those from a largely industrial subbasin (station I). The high subbasin yield from station $\mathrm{K}$ probably reflected excessive use of lawn and plant fertilizers in the subbasin. The subbasin represented by station I is steeply sloped and largely paved, and so would be expected to convey contaminated stormwater rapidly to the tributary.

Nitrogen and phophorus, which enter streams in agricultural and urban runoff, atmospheric deposition, and wastewater discharges, can cause algal blooms and excessive growth of higher aquatic plants. Nitrate-nitrogen can cause health problems in infants.

\section{Manganese Concentrations High in Hobbs Brook Subbasin}

Many samples from streams in the Hobbs Brook Subbasin had manganese concentrations above the USEPA's SMCL. Of the two

subbasins, the Hobbs Brook Subbasin contributed more manganese to the source area than did the Stony Brook Subbasin.

Manganese concentrations exceeded the USEPA's SMCL in more than 80 percent of samples collected at stations B, C, D, F, and G in the Hobbs Brook Subbasin. Forty to sixty percent of samples collected in the outflow from Hobbs Brook Reservoir (station E) exceeded the SMCL (fig. 3). Samples from station A, also in the Hobbs Brook Subbasin, and samples from station $\mathrm{K}$, a small tributary discharging directly to Stony
Brook Reservoir, rarely exceeded the SMCL.

Manganese occurs naturally in the study area and enters the streams in ground-water discharge. The differences in manganese concentrations may relate to the amount of oxygendepleted ground water that enters the streams near the sampling points. Manganese is highly soluble in oxygen-depleted water, but precipitates out when the water becomes oxygenated.

\section{ReservoirWater Quality}

A water-quality and ecological assessment of the system's three reservoirs identified seasonal variations in sodium, chloride, and other constituent concentrations in the reservoirs, and showed that ecological conditions improve as water moves through the system. Waldron and Bent (2001) discuss sample collection and analysis of physical, chemical, and biological data from the reservoirs.

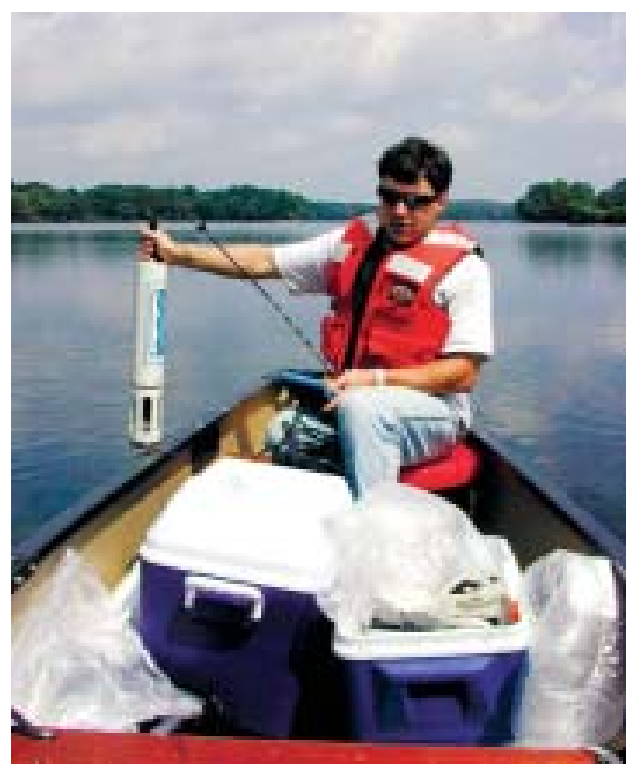

U.S. Geological Survey and Cambridge Water Department staff collecting reservoir samples.

\section{Seasonal Pattems Evident in ReservoirWater Quality}

In many reservoirs, the cooler bottom water becomes isolated from the warmer surface water during spring and summer. In Stony Brook Reservoir and Fresh Pond, air hoses mix the water to prevent this seasonal temperature layering and subsequent loss of dissolved oxygen from the stagnant bottom layer. Despite this mixing, some deep parts of both reservoirs remained isolated from the mixed surface layer. Loss of dissolved oxygen from these deep areas resulted in releases of ammonia-nitrogen, orthophosphate-phosphorus, and dissolved iron and manganese from the reservoir-bed sediments.

The highest reservoir concentrations of sodium and chloride were found in winter and spring, which suggests that winter and spring applications of road salt contributed most of the sodium and chloride in the system. The concentrations of sodium and chloride were higher in the Hobbs Brook Reservoir than in the Stony Brook Reservoir, but water from the less heavily developed Stony Brook Subbasin dilutes outflow from Hobbs Brook Reservoir and improves this condition to some extent.

Median concentrations of sodium exceeded the USEPA's DWEL of 20 $\mathrm{mg} / \mathrm{L}$ in all three reservoirs. Concentrations of chloride, however, were consistently below the drinkingwater SMCL.

\section{Ecological Conditions Improve as Water Moves through the System}

Throughout the Cambridge reservoir system, sedimentation and incorporation of nutrients and other potential contaminants into bottom sediments greatly affects water quality. Water from the Hobbs Brook Reservoir cascades through three basins before flowing into Stony Brook Reservoir. As water moves through each basin, nutrients and contaminants settle out of it. As a result, water from the Stony Brook Reservoir is of higher quality than the water entering the Hobbs Brook Reservoir.

Calculations of the reservoirs' ecological condition, as indicated by the Trophic State Index (Carlson, 1977), show the effects of the cascading. According to the calculations, the upper and middle basins of Hobbs Brook Reservoir were the most likely to produce blooms of nuisance algae. Although these basins were moderately to highly productive, the lower basin of Hobbs Brook Reservoir and Stony Brook Reservoir were intermediate in productivity. Fresh Pond was relatively unproductive and unlikely to produce algal blooms.

Concentrations of orthophosphatephosphorus likely control the growth of nuisance algae in these water bodies. In inland waters, phosphorus 
usually is the nutrient in shortest supply relative to the nutritional requirements of algae, and the molar ratio of nitrogen to phosphorus is a good indicator of the extent to which phosphorus may limit algal growth (Cooke and others, 1986). Ratios measured in Hobbs Brook and Stony Brook Reservoirs, and in Fresh Pond, indicate that algae in these water bodies run out of phosphorus long before they run out of nitrogen. As a result, it is likely that small increases in phosphorus loading from the drainage basins could stimulate algal blooms in the reservoirs, but increases in nitrogen loading alone probably will not.

Nitrogen and phosphorus may enter the water supply from bird and animal waste, precipitation, bank erosion, fertilizer, and stormwater runoff. They may cause increased turbidity, depletion of dissolved oxygen, and mobilization of contaminants from reservoir sediments (Cooke and others, 1986). During the study period, waterfowl and precipitation contributed insignificant amounts of nitrogen to Hobbs Brook Reservoir, but they contributed significant amounts of phosphorus relative to other sources.

\section{Study Results Aid Development of Innovative Water-Quality Monitoring Program}

From the results of this study, 10 of the tributary stations were selected for the water-quality monitoring program. These stations represent streams that contribute water directly to the reser-

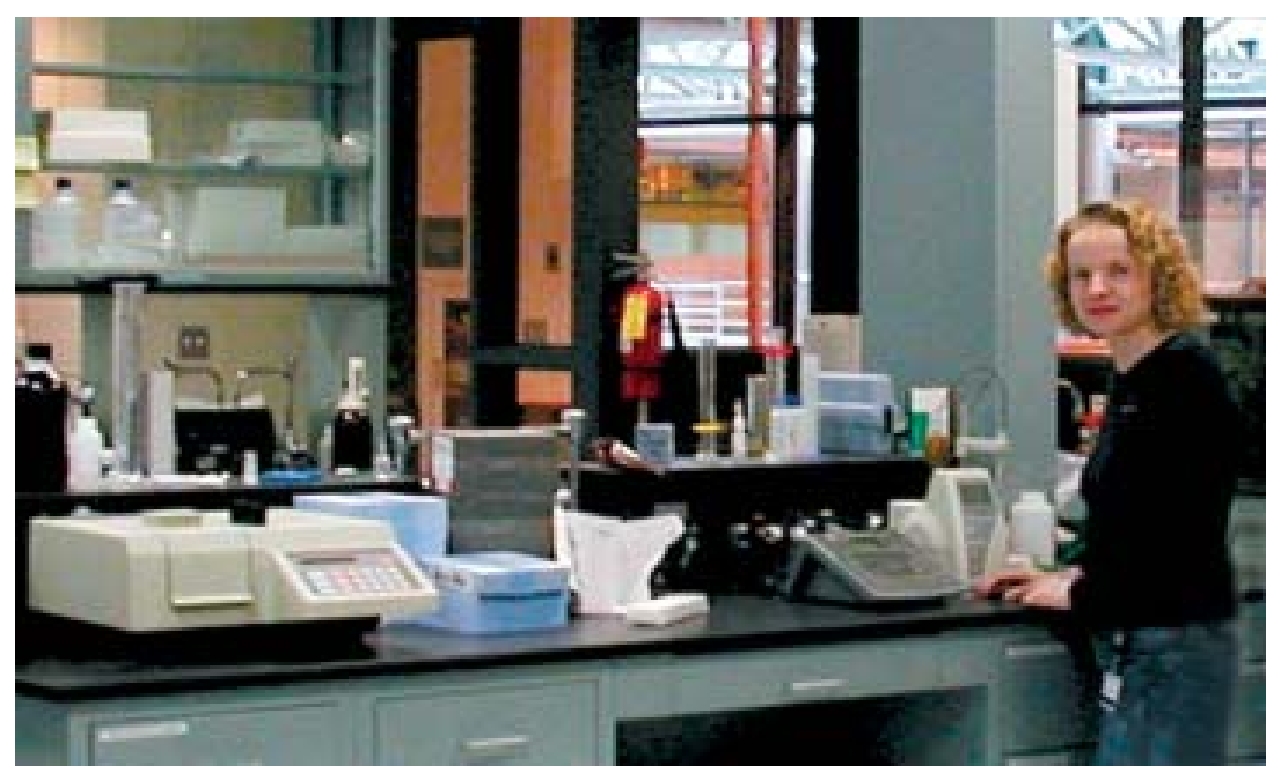

Figure 5. Cambridge Water Department Laboratory voirs and major tributaries, or integrate large areas of the drainage basin. Also, eight monitoring stations representative of the three reservoirs were identified and incorporated into the program.

In this program, the CWD is using established USGS protocols and standards for sample collection. By using these methods, the CWD can compare their data with previously collected USGS baseline data. This progressive program has made the CWD unique among local water-resource managers in the Northeast.

The monitoring program has four main elements. They include:

(1) routine monitoring of reservoirs and tributary streams during dry weather, (2) monitoring of streams, storm drains, and other outfalls, during storms, (3) continuous recording of stage and selected waterquality characteristics at critical sites, and (4) periodic monitoring of ground-water quality near Fresh Pond.

The CWD staff analyzes the samples at the CWD Laboratory (fig. 5), which is in a new water-treatment plant on Fresh Pond. The laboratory1 supports the CWD's Watershed, Treatment, and Distribution Divisions. A wide range of analytical equipment in the facility supports the increased demands of both the new treatment plant and the expanded watershedmonitoring program.

\section{USGS and CWDTeam Up on Stormwater Runoff}

The USGS and the CWD are also studying the effects of stormwater runoff on water quality in the tributaries and reservoirs. Roads, buildings, and other structures impervious to precipitation cover more than 8 percent of the Cambridge drinking-water source area. Rather than soaking into the ground, rain and snow that fall on the drainage basin may flow across these surfaces directly to the streams. As it flows, the water picks up and transports a variety of contaminants, including oil, grease, gasoline, cleaning agents, pesticides, plant nutrients from fertilizers, and bacteria from bird and animal waste.

This new study will measure changes in streamflow and the amounts of contaminants transported to the streams in stormwater runoff from many sources in the drainage basin. This information will be combined with records of continuously monitored stream conditions to provide real-time predictions of stormwater-contaminant loads. This will enable the CWD to monitor the effects of stormwater runoff on the water supply and to quickly identify contamination problems that may occur during storms. The CWD also will use this information as an "early warning system" to help guide management decisions in the event of an accidental release of hazardous material.

\section{References Cited}

Carlson, R.E., 1977, A trophic state index for lakes: Limnology and Oceanography, vol. 22, no. 2, p. 361-369.

Cooke, G.D., Welch, E.B., Peterson, S.A., and Newroth, P.R., 1986, Lake and reservoir restoration: Butterworths, Boston, Mass., 392 p.

Waldron, M.C., and Bent, G.C., 2001, Factors affecting reservoir and stream-water quality in the Cambridge, Massachusetts, drinking-water source area and implications for source-water protection: U.S. Geological Survey WaterResources Investigations Report 00-4262, 89 p.

U.S. Environmental Protection Agency, 1998, Safe drinking water-Sodium in drinking water: Accessed online March 30, 2002, at http:// www.epa.gov/safewater/ccl/sodium.html/.

U.S. Environmental Protection Agency, 2001, Current drinking water standards-National secondary drinking-water regulations: Accessed online March 30, 2002 at http://www.epa.gov/ safewater/mcl.html/.

Report by -

Marcus C. Waldron, Matthew G. Cooke, and

Christopher M. Ragnelli

Layout and graphic design by -

Christine T. Mendelsohn

For More Information:

District Chief

U.S. Geological Survey

10 Bearfoot Road

Northborough, MA 01532

http://ma.water.usgs.gov/ 